\title{
Analytical maps as a basis for understanding the development of rural architecture
}

\section{Zdeněk Poloprutský*, Petr Soukup}

Czech Technical University in Prague, Faculty of Civil Engineering, Department of Geomatics, Czechia

* Corresponding author: zdenek.poloprutsky@fsv.cvut.cz

\begin{abstract}
This article deals with the creation of maps that depict the development of selected villages in Czechia in the 19th and 20th centuries. These maps are used for the artistic and historical research of rural architecture, which focuses on the type and detail of the surveyed buildings in the selected time period. Its results can be interpreted in a wider cultural context of the respective rural region. The maps of the development of rural architecture were created on the basis of a detailed analysis of available archival maps. The article describes the practical experience with the creation of these maps, contains an overview and description of available archive maps and the procedure of their processing using geographic information system (GIS) tools. The interactive presentation of the created maps on the Internet is also discussed.
\end{abstract}

\section{KEYWORDS}

development of rural architecture; archival maps; georeferencing of maps; vectorization of maps; web-map-presentation

Received: 26 June 2019

Accepted: 4 November 2020

Published online: 18 December 2020

Poloprutský, Z., Soukup, P. (2021): Analytical maps as a basis for understanding the development of rural architecture.

AUC Geographica 56(1), 31-43

https://doi.org/10.14712/23361980.2020.22

(C) 2020 The Authors. This is an open-access article distributed under the terms of the Creative Commons Attribution License (http://creativecommons.org/licenses/by/4.0). 


\section{Introduction}

The beginning of the 21st century is associated with a rapid development of Information and Communication Technologies (ICT), which have gradually affected most areas of human activity, including cultural heritage. In the field of monitoring the development of rural architecture, it is primarily the use of Geographic Information Systems (GIS).

In Bohemia and Moravia, the rural architecture has been influenced by intense political, economic and social changes taking place since the second half of the 19th century. In particular, they involved the abolition of drudgery (1848), the establishment of the cadastre unit institute and building legislation, i.e. specification of construction management, fire regulations, and the arrival of qualified architects, etc. The gradual emergence of industry (19th century) and large migration after World War I and World War II (20th century) had major influence on the development of villages. In addition, the appearance of rural architecture has been changing rapidly since the end of the 20th century.

During the research into rural architecture, the main focus often aims at the Building Archaeology Survey and metric survey documentation of the oldest preserved medieval buildings and their fragments. The study of rural Baroque and Classicism architecture (Mencl 1980) also attracts a great deal of attention. Rural architecture of the second half of the 19th century and its development during the 20th century have been highlighted since the 1990s (Dittrich 1990; Kuča, Kučová 1995; Škabrada 1999).

Generally, the approach to research into rural architecture is divided into two types:

1. individual,

2. areal.

In the first case, it is usually an Operative Survey (Bláha et al. 2005) or a Building Archaeology Survey (Beránek, Macek 2015; Pešta 2014) or a metric survey documentation (Veselý 2014; Pavelka 2017; Poloprutský 2018) of a specific building or a block of buildings. An interesting source of information about rural architecture can be the projects of village buildings, which capture objects in their original form, i.e. not obscured by later modifications, rather than on real buildings (Ebel, Škabrada 2016).

In the second case, it is usually an area survey in which attention is focused on a particular region. With this approach, archival maps of various types and ages can be used to describe, monitor and analyse anthropogenic and environmental phenomena that have been involved in and contribute to the development of the region of interest of this article. Recent research studies in Czechia which deal with thematic changes of the landscape over time are often focused differently in their specific objectives, e.g. on the development and reconstruction of extinct villages in the Ústí Region (Brůna et al. 2015a, 2015b) or the development and reconstruction of the historical Vltava River valley (Cajthaml, Kratochvílová, Janata 2019).

Valuable data sources for landscape and urban development analyses are large-scale maps created in various historical periods as well as digital orthophotos - historical (Adami 2015; Cogliati et al. 2017) and contemporary. In these approaches, advanced GIS tools can be successfully applied (Liu, Wang, Long 2010; Čurovič, Popovič 2014; Adami 2015).

The article provides an overview of old and current large-scale map datasets available in Czechia. The basic properties of maps with regard to the solved problems are stated (Chapter 2). The main goal of the article is to apply the basic methods of processing old maps (georeferencing, vectorization, topology control and online presentation - Chapter 3 ) for the creation and presentation of maps of the built-up area development (Chapter 4). The described workflow identifies problems that occurred during processing and lists their solutions that can be inspiring when processing similar tasks.

Created maps of the built-up area development are used for Artistic and Historical Research of processed localities (Hůrková, Mezihoráková 2018, 2019).

\subsection{Artistic and historical research}

Artistic and Historical Research focuses on a specific part, an element or a type of building under investigation in the chosen time period. Its results can further be developed and interpreted in a wider cultural context of the respective rural region. In this way, it is possible to describe the cultural and social environment of the given rural region and external influences which have guided its future development in the given time period (Hůrková, Mezihoráková 2016). Artistic and Historical Research is the domain of the ÚDU staff.

In the future, the results of Artistic and Historical Research can be used as a supplement to the Building Archaeology Survey (Pešta 2014; Beránek, Macek 2015). Artistic and Historical Research consists of four basic parts:

1. background research of available historical sources and literature,

2. analysis of urban development based on the analysis of large scale maps from the 2nd half of the 19th century to the present,

3. survey of rural buildings in the region and selection of the building which formally and by style best characterizes rural architecture in the region (Poloprutský 2018),

4. interpretation, presentation and archiving of the results.

\subsection{Maps of built-up area development}

The maps of the built-up area development are made on the basis of a detailed analysis of available archive maps and subsequently serve for the analysis of 
building development. In the light of these facts, these maps are referred to as analytical maps in the text below. In the early stages of research, it has proven useful to produce analytical maps of two types:

1. Summary maps of the development of a built-up area which show the buildings (their outline) in all used underlying maps.

2. Detailed maps of the development of a built-up area which show the buildings in terms of building construction in the two oldest time periods. These maps benefit from the fact that in the maps of a Stable Cadastre, it is possible to tell from the colour of the filling of the building whether it is a brick or wooden one.

Analytical maps capture the transformation of the ground plans of buildings. However, caution must be paid - there is a number of buildings that were completely rebuilt although their ground plan has been preserved. By comparing the time layers, it is possible to deduce interesting facts from analytical maps that can be approximately dated (Poloprutský 2018):

- Ground plan of the building has not changed - it is likely that the original core is preserved in the building, although the facades of the building can be completely changed;

- Ground plan of the building has changed - building modifications have been made;

- Ground plan of the building has shifted on the plot - the original building has been replaced by a new building;

- Change in colour of the building filling - the building was rebuilt using another building material (wood - brick).

An essential prerequisite for the creation of analytical maps of surveyed sites is the existence and availability of a sufficient number of base-maps, which may be supplemented by other data sources such as Aerial Survey Photographs or Orthophotos.

\section{Base datasets}

First, it was necessary to search for archival datasets that show the main subject of research - buildings with sufficient detail and accuracy. Detailed maps charting the whole territory of today's Czechia cover the time period of almost 200 years. The quality of individual map-sets is influenced by the purpose for which they were made, the available and used technical means, the financial possibilities, as well as other factors, and does not apply proportionally: the older the map the lower the quality. For a correct interpretation of the content of underlying maps (Hauserová, Poláková 2015), it is favourable to know these technicalities, and therefore we give an overview of the basic characteristics of the used data sources (Bumba 2009; Geoportal ČÚZK 2020). Generally, data sources can be divided into archival and current datasets by the date of creation.

\subsection{Archival base datasets}

Archival maps made for cadastral purposes are kept and made accessible to the public mainly by the Central Archive of Surveying and Cadastre (ÚAZK). The most frequently used maps are scanned and continuously published on its website (ÚAZK 2020). Scanned maps can be ordered through the E-shop of the $\check{C} U Z K$ Geoportal (Geoportal ČÚZK 2020). Maps that have not been scanned can be requested and examined in the ÚAZK study room where they can also be scanned. The issue of archive documents is charged according to the current price list.

The following map titles are taken from official sources (Geoportal ČÚZK 2020; Terminological Dictionary 2020). The overview of the maps is presented in chronological order (from the oldest).

Imperial Obligatory Imprints of the Stable Cadastre (CO, Figure 1) were made on the basis of the Imperial Patent of 1817, which established the Stable Cadastre. Cassini-Soldner's projection was used as the map projection; for Bohemia the Gusterberg datum of cadastre coordinates was used, and for Moravia and Silesia the St. Stephen datum of cadastre coordinates was used. Maps were created by using a method of the plane table in the fathom scale of $1: 2,880$ directly in the field. Imperial Obligatory Imprints were not used for plotting additional changes in the field, and thus depict the landscape in its original state from the mapping period (Bohemia 1826-1843, Moravia and Silesia 1824-1836). Maps were manually coloured. It was a unique map series, which has still been used in a large part of Czechia in digital form until today. Imperial Obligatory Imprints generally belong to the most demanded archival maps.

Original maps of the Stable Cadastre (OM, Figure 2) are original maps created during the mapping of the Stable Cadastre (one of the copies served as an Imperial Obligatory Imprint). The changes that occurred in the field were not continuously drawn into the maps and therefore the maps gradually became obsolete.

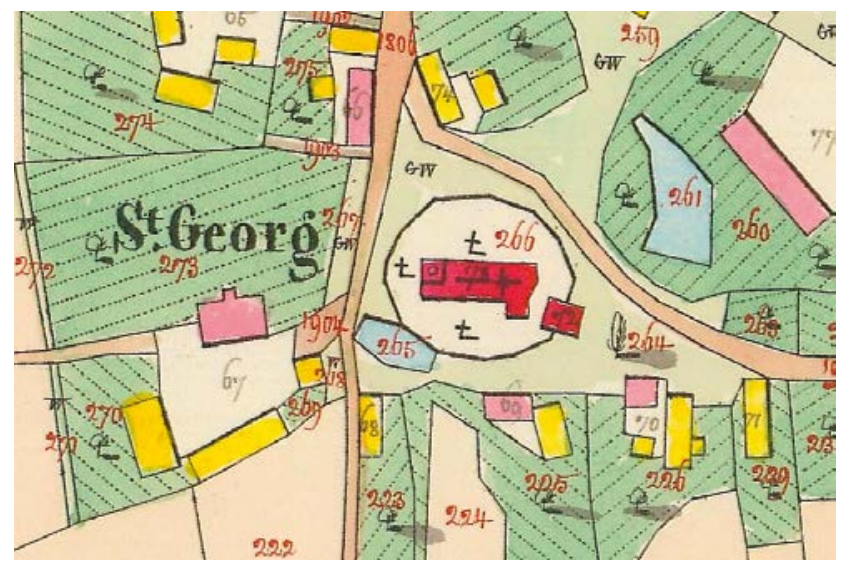

Fig. 1 Imperial Obligatory Imprint (1840), the centre of the village of Jasenná (Náchod District), data: ÚAZK. 


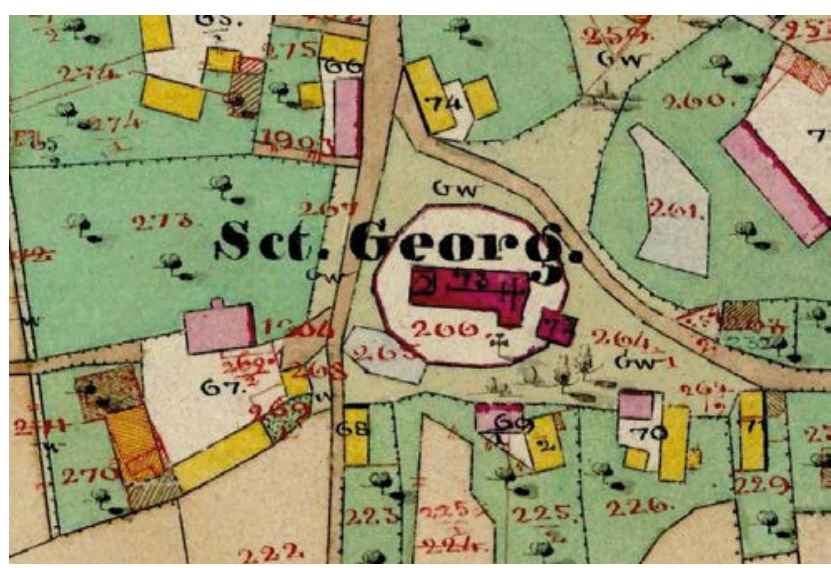

Fig. 2 Original map (1877), the centre of the village of Jasenná (Náchod District), data: ÚAZK.

In 1867, it was decided to perform a one-time update (reambulation) of maps. Unfortunately, due to the lack of time, changes were often mapped and plotted less accurately than the original mapping. The changes were drawn into the original maps by red colour for highlighting. When the drawing became confusing due to a large number of changes, the map was redrawn in its current valid state.

Correction sheets of the Stable Cadastre (EM, Figure 3) were depicted based on the legislation of 1883, which introduced the obligation to keep maps in accordance with reality (obligation to report changes of owners). The coordinate system and the content of these maps remained the same, only from 1887, new maps were formed in a decimal scale, usually $1: 2,500$. On the basis of numerically measured geometric plans, the changes in maps were sketched in red colour. If the drawing became confusing due to a large number of changes, the map was redrawn in its current valid state.

All the above-mentioned types of maps of the Stable Cadastre are maps of a selected area, i.e. the drawing does not cover the entire map sheet, but ends at the border of a cadastral unit. In terms of built-up area development studies, it is important that the maps distinguish wooden buildings from brick ones.

All types of maps of the Stable Cadastre, i.e. CO, OM and EM, are available in the raster scanned JPG format with a resolution of $300 \mathrm{DPI}$. With the exception of CO, where the mapping year is clearly stated, it may not be easy to reliably determine the date to which the map refers, i.e. when the map was completed. Sometimes, the date can be read from a handwritten note on the edge of the map; sometimes, it is necessary to consult the problem with the ÚAZK staff; and sometimes, the exact date of the map remains uncertain.

Land Cadastre maps (PK, Figure 4) were made in Křvova's projection in the Datum of the Uniform Trigonometric Cadastral Network (S-JTSK) according to a law from 1927 and related instructions. The new mapping was carried out only in a smaller part of the territory, preferably in locations with major changes (usually in a reference scale of $1: 2,000$ for rural and $1: 1,000$ for built-up areas). In other localities, the maps of the Stable Cadastre remained valid.

Land Cadastre maps are provided by ÚAZK in a binary (black and white) CIT format with a resolution of 400 DPI without georeferencing (individual map sheets) or as one file (complete cadastral unit) georeferenced to the coordinate S-JTSK system. The relatively low scanning resolution and especially the used data-format made the drawing of the scanned map often difficult to read. The date of completion of the drawing into the map must be discussed with the locally relevant cadastral office, where the map is stored. There, it is also possible to request a new, i.e. higher quality, scan of the map.

State Maps $1:$ 5,000 - derived (SM05, Figure 5) were made for the needs of state administration in the years of 1950-2000. The topography was derived from current cadastral maps. The maps also contain hypsography, which was taken from the most suitable existing data (usually a smaller scale). The maps can be used in a situation when the original cadastral

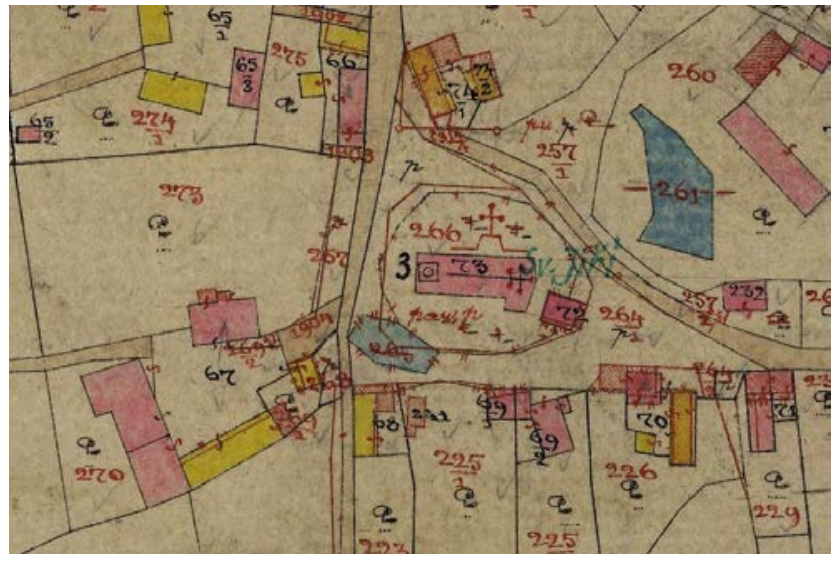

Fig. 3 Correction sheet (1939), the centre of the village of Jasenná (Náchod District), data: ÚAZK.

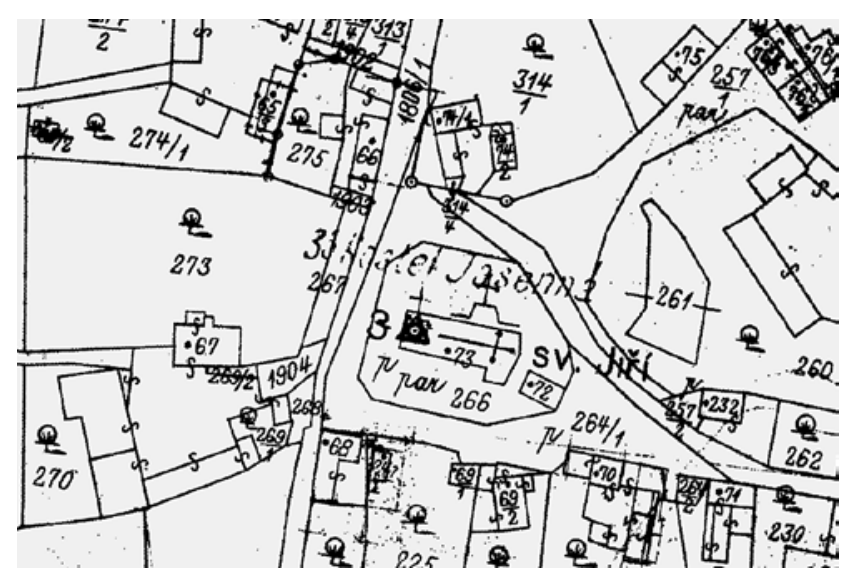

Fig. 4 Land Cadastre map (1955), the centre of the village of Jasenná (Náchod District), data: ÚAZK. 


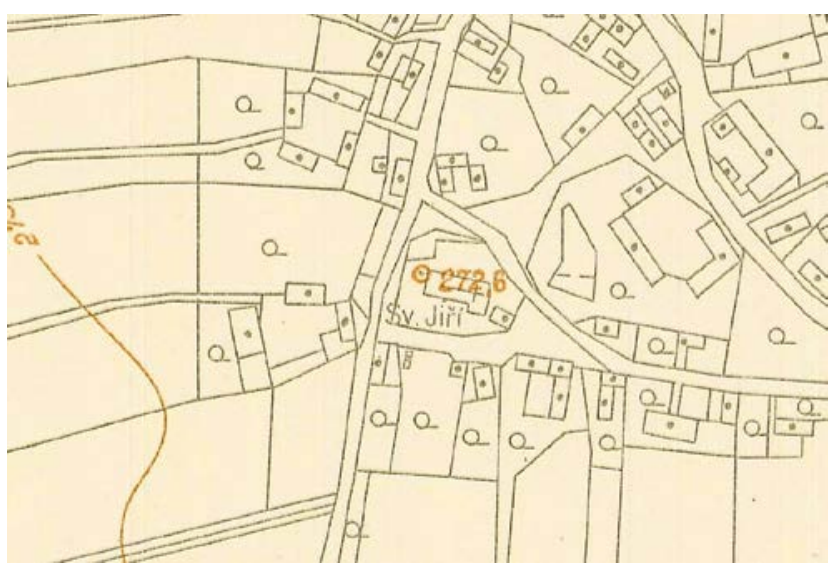

Fig. 5 State Map 1 : 5,000 - derived (1953), the centre of the village of Jasenná (Náchod District), data: ÚAZK.

maps have not been preserved for the given period. A smaller map scale provides less detail, even with regard to the shape of buildings. The maps are scanned at a resolution of 300 DPI and provided in the JPG format.

Maps of the Unified Land Registry (JEP) were made in the years of 1956-1964 recording only actual land use relations (not ownership relations). For the measurement and plotting changes in the map, simplified procedures and looser tolerances were allowed, which resulted in less geometrically accurate maps.

Maps of the Registry of Real Estate (MEN, Figure 6) were introduced by legislation in 1964 . The projection and the coordinate system remained unchanged. The drawing continuously covers the whole map sheet - individual maps of selected areas were connected; irregularities at the interface drawing are partially aligned with the consequence of a local loss of geometric precision.

The maps of JEP and MEN are scanned and provided in the JPG format with a resolution of $300 \mathrm{DPI}$. These maps may be available in several editions of different dates.

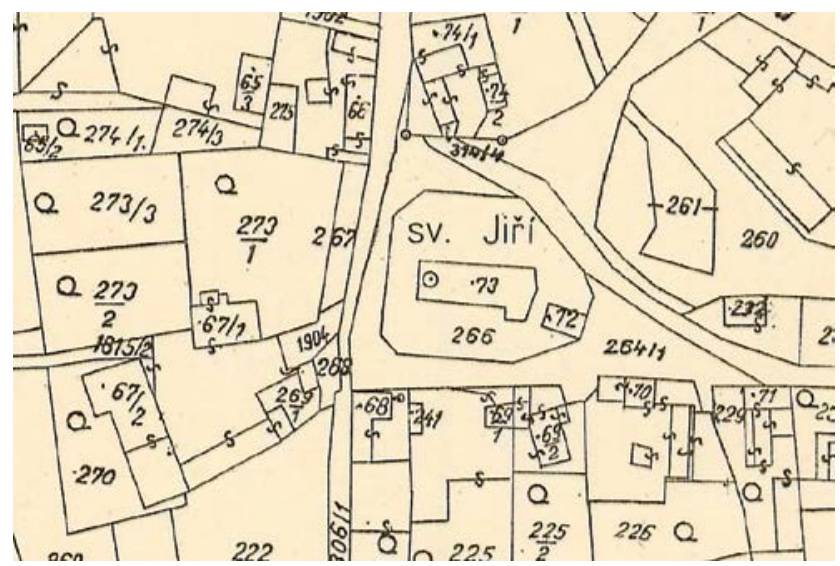

Fig. 6 Maps of the Registry of Real Estate (1964), the centre of the village of Jasenná (Náchod District), data: ÚAZK.

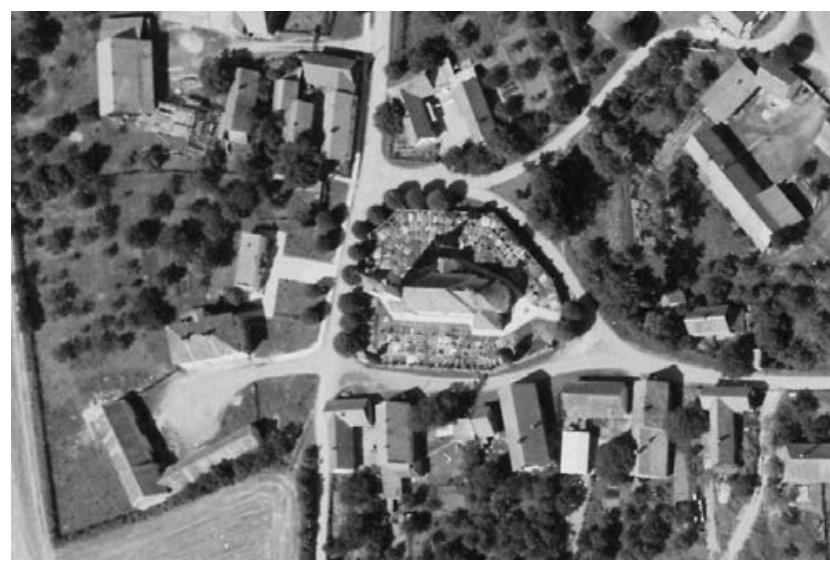

Fig. 7 Aerial survey photograph (1975), the centre of the village of Jasenná (Náchod District), data: ÚAZK.

Aerial survey photographs (LMS, Figure 7) have been taken since 1936. The photograph scale is smaller than in the previously mentioned base maps, and their content is affected by the weather at the time of photography, but they capture non-generalised situations and represent a usable data source. If a relief elevation model is known, the photographs can be converted to an orthophoto (Hodač, Zemánková 2018).

The National Archive of Aerial Survey Photographs is administered by the Military Geographic and Hydrometeorological Office in Dobruška. Original aerial photographs are gradually digitized in cooperation with the Czech Office for Surveying, Mapping and Cadastre (ČÚZK). Some photographs are available on the website of the archive (LMS 2020).

Other usable historical maps of a local scope (various thematic maps, manor maps, homestead plans, etc.) may be a part of the funds of local regional archives.

\subsection{Current base datasets}

From the current base datasets Cadastral maps of the Real Estate Cadastre and the Orthophoto of the Czech Republic can be used to monitor the development of built-up areas.

Maps of the Real Estate Cadastre (KN, Figure 8), i.e. current cadastral maps, are made according to legislation from 2013 (Cadastral Decree 2013). Today, cadastral maps exist in digital vector form in the S-JTSK system (EPSG: 5514) for almost the whole territory of Czechia. The maps, created by new mapping or by reworking of numerical surveys, are called Digital Cadastral Maps (DKM); the maps created by the digitization (vectorization) and transformation (georeferencing) of analogue maps are called Digitalized Cadastral Maps (KMD). On a very small part of Czechia, there are still maps in the Stable Cadastre system (KM-D) or even in analogue form.

Cadastral maps in digital vector form can be freely downloaded from the website for individual cadastral 


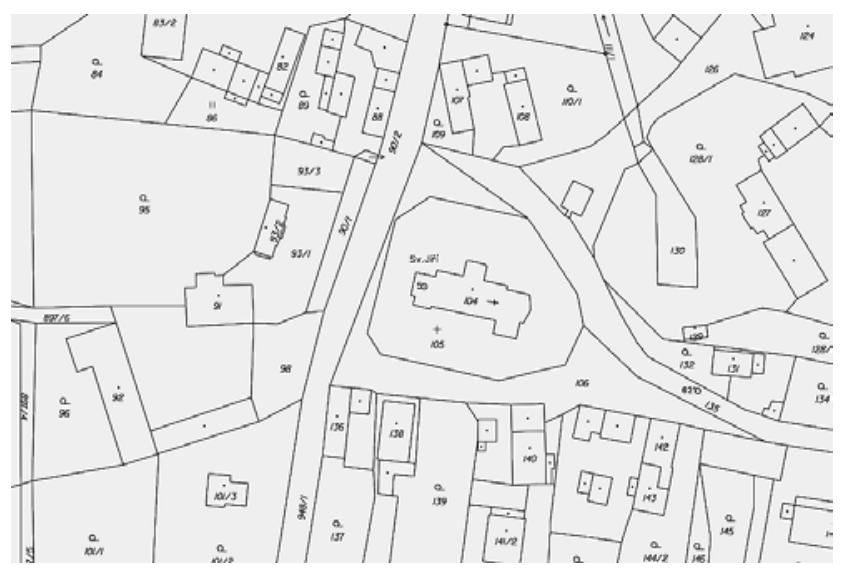

Fig. 8 Map of the Real Estate Cadastre (2018), the centre of the village of Jasenná (Náchod District), data: ÚAZK.

units (Geoportal ČÚZK 2020) in several types of vector formats (DGN, DXF, SHP, VFK). Analogue cadastral maps in the CIT raster format can be downloaded from the website (for a fee).

The Orthophoto of the Czech Republic (Figure 9) depicts the current non-generalised earth surface at the time of photography. Currently, it is produced in a two-year period with a pixel size of 0.20 meters. The orthophoto is available as a data file in the JPG format in a range of $2.5 \times 2 \mathrm{~km}$, i.e. map layout of the State map at a scale of $1: 5,000$ (for a fee) or as a Web Map Service (free). The orthophoto may contain buildings that are not drawn into the cadastral map - they are not subject to the cadastre or have not yet been measured and displayed.

\section{Methods for processing datasets}

During the processing of analytical maps, a number of methods which are briefly presented in the following text was used.

\subsection{Georeferencing}

In this article, georeferencing is understood as the placement of raster maps in a known coordinate reference system. The georeferencing operation is performed by a geometric transformation determined on the basis of identical points, i.e. points that are simultaneously drawn on both maps - a georeferenced map and a reference map (Cajthaml 2012).

Identical points determine the accuracy of the transformation. It is necessary to choose these points in areas that did not change during the gap between the creations of both maps. The most common identical points are corners of important buildings, distinct breakpoints on the cadastral boundary, common points of two or more parcels, etc. Identical points should be distributed throughout the area of interest

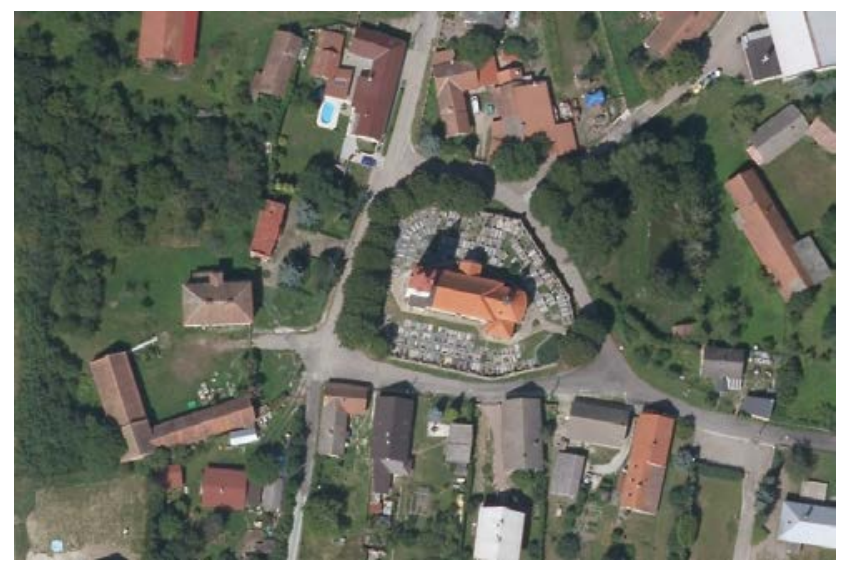

Fig. 9 Orthophoto of the Czech Republic (2018), the centre of the village of Jasenná (Náchod District), data: ÚAZK.

as evenly as possible. Sometimes, it is difficult to find a sufficient number of appropriately spaced identical points. In that case, it is necessary to take into account the possible impacts on the accuracy of the resulting transformation.

For the georeferencing of scanned map sheets, affine transformation is often chosen (Luhmann et al. 2014), which reflects the various shrinkage of a map sheet in longitudinal and transverse directions. With an excessive number of identical points, i.e. with more than three, the transformation accuracy can be estimated and offsets at identical points can be calculated by the least squares adjustment. The use of a higher degree of transformations leads to smaller deviations at identical points, but to greater local deformations.

\subsection{Vectorization}

The vectorization of the map means "reworking a map in analogue form, or a digital map in raster form, into vector form" (Terminological Dictionary 2020). During vectorization, a digital vector presentation of spatial elements is created. Vectorization can be performed manually one by one point, or by the use of various forms of automation. The manual vectorization method is very time-consuming, but it is often the only way to get a well-usable vector map. With manual vectorization, individual map elements can be divided into thematic layers and additional properties (attributes) may be added to them.

\subsection{Topology control}

Vector map elements form a topology that is understood as "defining the structure elements of geosystems based on their relationships connectivity (interconnection) and continuity (relative positions); map elements create topological structures consisting of nodes, edges, and walls" (Terminological Dictionary 


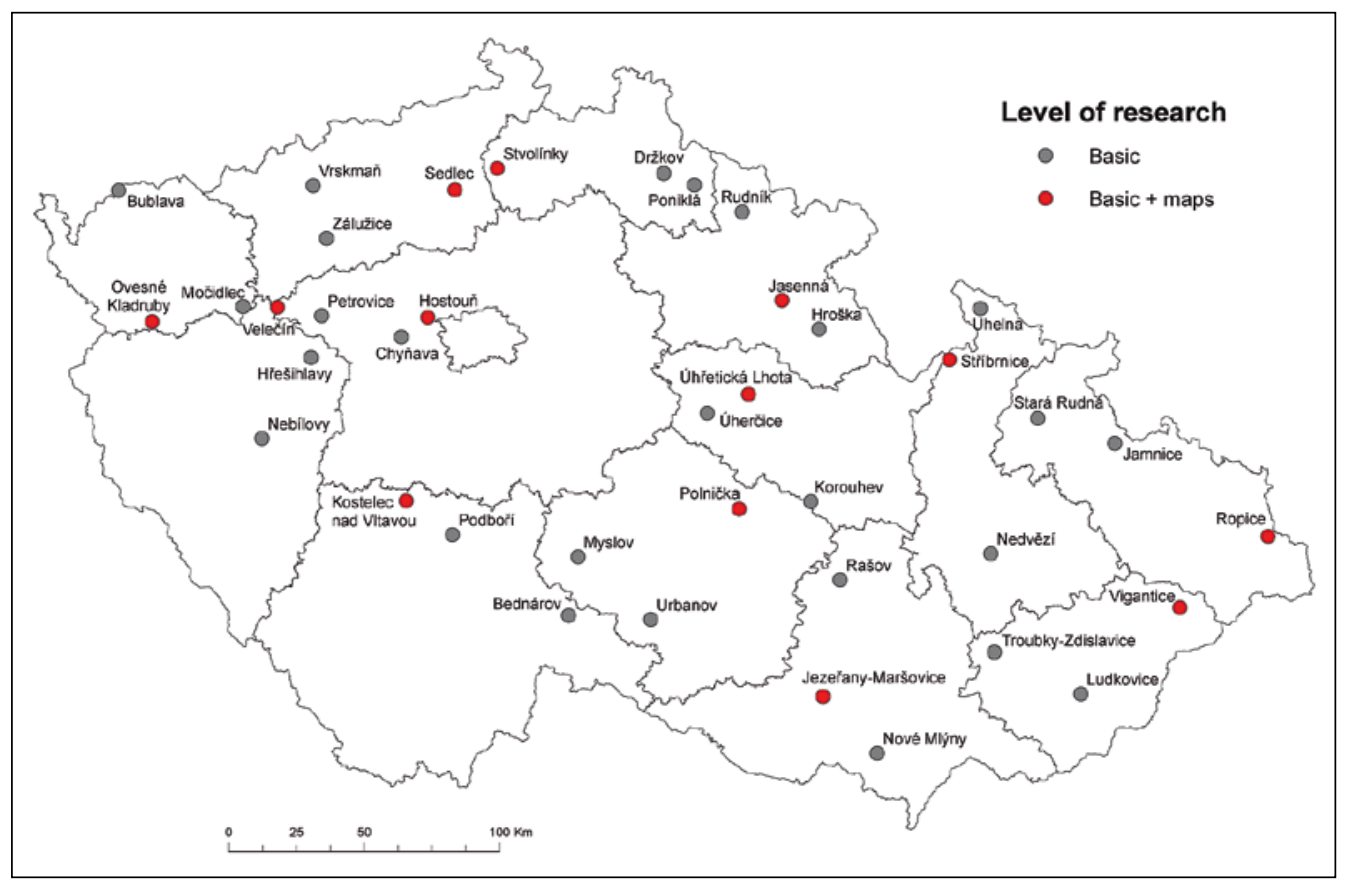

Fig. 10 Location of examined villages in Czechia.

2020). From a practical viewpoint of the vectorization of a map, it is the verification that the drawing does not contain free line ends, intersections of lines without intersection points, isolated points etc. It would not be possible to perform subsequent spatial analyses correctly without removing these imperfections. Their general theoretical overview is beyond the scope of this article, therefore only the specific process that was used is described in subsection 4.4 .

\subsection{Online presentation of maps}

Digital maps can be made available to a wide range of users on the Internet websites nowadays. An attractive online presentation of maps requires the use of tools that offer interactivity, i.e. at least the possibility of changing the scale of the map display, shifting the viewport, eventually the possibility of working with layers or the availability of additional information about each map element. For complex solutions, it is possible to talk about a certain information system based on a concrete map.

Generally, presented digital maps can be divided according to format into raster and vector maps. For displaying larger raster maps, it is favourable to use a solution that allows selectively downloading and displaying only the necessary data based on the current viewport and the display scale. For this purpose, the so-called pyramid of raster tiles is usually used. Presenting maps in the vector format allows zooming in and out of the drawing at any time without a loss of display quality. Complex map contents can be divided into separately viewable thematic layers.
Generally, individual maps, thematic layers or additional external data sources may be in different coordinate systems. For a positionally correct common view of all parts of the map, it is necessary to ensure the appropriate transformation of their display into a uniform coordinate system.

Today, many applications allow advanced ways of online presentations of raster and vector data (e.g. Tile Map Service, Zoomify, OpenStreetMaps, OpenLayers, GeoServer, MapServer, ArcGIS Server, etc.). For digital maps with a richer or significantly overlapping content, it is preferable to allow users to turn on and off the display of individual thematic map layers. In this case, it is more relevant to use maps in the vector format, which allows sufficient map zooming without a loss of display accuracy in addition. Choosing the right application is an important moment in the solution of every project.

\section{Workflow for processing datasets}

For clarity, the creation of maps of the built-up area development can be divided into several steps which are described below.

\subsection{Selection of examined villages}

First, it was necessary to choose suitable villages. The focus was on villages that have not been subjects of intensive research so far, but which contain significant values of rural architecture. The village selection was made by the ÚDU working group (ÚDU 2020). In each administrative region of Czechia (with the exception 
of the Prague region, i.e. a total 13), three villages were selected and included in the basic Artistic and Historical Research. One village out of three was then selected for the processing of built-up area development maps.

The existence and availability of suitable base datasets is an essential prerequisite for the creation of analytical maps. For some villages originally considered for processing, a sufficient number of archival maps was unfortunately not found and therefore they had to be replaced by other villages. The locations of selected villages are shown in Figure 10.

\subsection{Collection of base datasets}

The availability and quality of datasets differed for individual villages. The basic sets of archival maps were searched and ordered from the ČÚZK Geoportal E-shop (ČÚZK Geoportal 2020). Based on a concluded contract specifying the scope and terms of use of the data, it was possible to download the datasets from the website after paying the fee. Some archival maps have not been scanned yet and are therefore not available in this way. Such documents had to be searched directly in the archives (Národní archiv, ÚAZK 2020). Searched maps can either be photographed or scanned by the archive staff. When some of the maps could not be found, it was necessary to look for alternative data sources, such as archival Aerial Survey Photographs, or the State Maps 1 : 5,000 derived (SM05).

Based on the processed time period and available base datasets, it was determined that four archival base datasets would always be used to create analytical maps, displayed as evenly as possible over time. These maps were supplemented by the current cadastral map. The base datasets used for each site are listed in Table 1. For archival base datasets, the type of map and the year to which it relates are shown. The current cadastral map is differentiated according to the type of DKM and KMD with the percentage of the cadastral unit coverage. The last column of the table shows the number of created map sheets of analytical maps.

\subsection{Pre-processing of base datasets}

Before the processing of analytical maps, it was necessary to modify the used datasets. The whole process consisted of several follow-up steps and was implemented using ESRI software - ArcGIS.

\subsubsection{Georeferencing}

The S-JTSK national coordinate system (EPSG variant: 5514 i.e. S-JTSK East North - the $\mathrm{X}$ axis points to the East, the $\mathrm{Y}$ axis to the North) was chosen as the reference coordinate system. The current cadastral map was chosen as the reference map, i.e. DKM or KMD, which can be considered as the most accurate base map. Affine transformation was used for the georeferencing of all archival base maps.

An extensive number of identical points was used to transform each map sheet. In ArcMap software, the total georeferencing accuracy is determined by the Total Root Mean Square (RMS) Error value. Its value ranged from 1.0 to $6.8 \mathrm{~m}$, which is an accuracy that corresponds to the level of accuracy of the used base maps. The results of the georeferencing stage are sets of raster maps transformed into a common coordinate system.

\subsubsection{Vectorization}

The built-up area was the primary subject of vectorization, i.e. the drawing of buildings in all archival base maps. For easier orientation in maps, the following items were also vectorized from the oldest maps (Imperial Obligatory Imprints of the Stable Cadastre):

Tab. 1 Summary of used base datasets.

\begin{tabular}{|c|c|c|c|c|c|c|c|c|}
\hline ID & Village & 1st set & 2nd set & 3rd set & 4th set & DKM & KMD & MS \\
\hline 1 & Hostouň & CO 1840 & OM 1876 & PK 1938 & JEP 1961 & 65 & 35 & 1 \\
\hline 2 & Jasenná & CO 1840 & OM 1877 & EM 1939 & LMS 1975 & 100 & 0 & 2 \\
\hline 3 & Jezeřany-Maršovice & CO 1825 & OM 1873 & PK 1940 & MEN 1963 & 0 & 100 & 2 \\
\hline 4 & Kostelec nad Vltavou & CO 1830 & OM 1873 & EM 1914 & MEN 1967 & 0 & 100 & 1 \\
\hline 5 & Ovesné Kladruby & CO 1839 & EM 1887 & LMS 1956 & MEN 1982 & 48 & 52 & 1 \\
\hline 6 & Polnička & CO 1838 & OM 1872 & PK 1953 & MEN 1967 & 100 & 0 & 2 \\
\hline 7 & Ropice & CO 1836 & OM 1880 & PK 1930 & MEN 1980 & 60 & 40 & 3 \\
\hline 8 & Sedlec & CO 1843 & OM 1872 & PK 1939 & MEN 1978 & 0 & 100 & 1 \\
\hline 9 & Stř́brnice & CO 1835 & OM 1871 & PK 1955 & MEN 1982 & 0 & 100 & 2 \\
\hline 10 & Stvolínky & CO 1843 & EM 1897 & PK 1931 & LMS 1954 & 100 & 0 & 2 \\
\hline 11 & Úhřetická Lhota & CO 1839 & OM 1876 & PK 1949 & MEN 1964 & 100 & 0 & 1 \\
\hline 12 & Velečín & CO 1841 & OM 1875 & EM 1908 & PK 1964 & 48 & 52 & 1 \\
\hline 13 & Vigantice & CO 1833 & EM 1905 & PK 1950 & MEN 1982 & 6 & 94 & 2 \\
\hline
\end{tabular}


- basic road network - roads, paths, or railways,

- waters - watercourses and surface water (ponds and lakes),

- boundaries of cadastral units,

- small sacral objects (chapels, crosses and wayside shrines).

The descriptive or registration numbers of buildings, parcels of the Real Estate Cadastre and the boundaries of cadastral units were taken from the current cadastral map. Vectorized elements were stored in the file geodatabase in the form of feature classes. In the attribute table of a feature class that contains buildings, additional columns have been added to the columns automatically generated by ArcMap:

- Type - a wooden or a brick building,

- Category - buildings,

- Year - dating of the map,

- Note - an optional item.

The routine vectorization process contains an element of "sophisticated assessment" in this case, because the accurate georeferencing of maps does not lead to an identical representation of the same building on individual maps. Each map of the cadastral unit for a given year can be viewed as a layer of the map composition in the used software. Due to many factors, e.g. inaccuracies of mapping, drawing, scanning, georeferencing, vectorization, etc., an identical building is displayed in a slightly different position in each map layer. Our effort was to eliminate these graphical errors in maps and to capture only real changes in the position and shape of individual buildings (extensions, reconstructions). Thus, the identical building had to be vectorized in the same position in all maps. The assessment of the identity, or, on the contrary, the dissimilarity of buildings was an essential vectorization skill, with some degree of subjectivity.

As already mentioned, the current cadastral map was chosen as the reference map. The building which was detected on the archival map as identical to the building on the reference map has been vectorized to the position of the building on the reference map (in mode snapping to existing points). This eliminated the inaccuracies of map drawing, which would otherwise complicate any subsequent analyses.

The vectorization proceeded from the oldest map to more recent maps. First, the map of the Imperial Obligatory Imprint was vectorized. In order to speed up the process, another map (time stage) was vectorized above the copy of this map. Only subsequent changes were manually incorporated: new buildings, extinct buildings, reconstructions, extensions.

The described vectorization method had to be performed manually. This was the most time-consuming stage of the process. The sets of vector maps with attributes are the result of the vectorization stage.

\subsubsection{Topology control}

Two simple basic topological rules were checked in drawing each vectorized map:

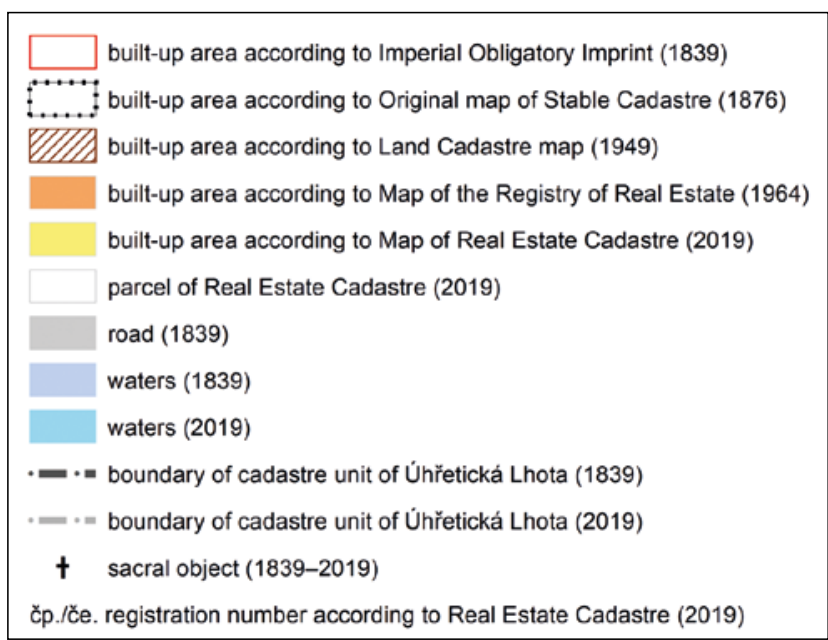

Fig. 11 Example of the summary map legend.

1. whether there is no overlap of two or more polygons,

2. whether the continuity of individual edges of polygons is not interrupted.

Any found errors had to be removed by the editing functions of the software. This processing step resulted in topologically pure data, prepared for subsequent analyses.

\subsection{Creation of analytical maps}

As mentioned in the Introduction to the article, the analytical maps of the built-up area development were divided into two variants: summary and detailed.

A summary map shows the built-up area from all selected data sources ( 4 archive and 1 current) organized into individual thematic layers. Since individual buildings usually appear in multiple base maps at the same time, it was necessary to choose the appropriate way to display them. The archival thematic layers of buildings are displayed (from the oldest) by the perimeter, the symbol on the perimeter, the hatching and the area fill. The current state of buildings is shown by a transparent filling of the area (Figure 11). In this way, it is possible to clearly distinguish all time layers of individual buildings on the map.

A detailed map shows the built-up area of the two oldest base maps, showing the development of the building construction of buildings. On the maps of the Stable Cadastre, it is possible to distinguish from the colour of the building filling whether it is a brick or a wooden building.

In terms of the occurrence of buildings on both of the used base maps, two situations could have been detected. A building occurred on both base maps or on one base map only. If a building (or a part of a building) was on both base maps, four options were distinguished (Intersect function):

1. Wooden building remained wooden (woodenwooden) 


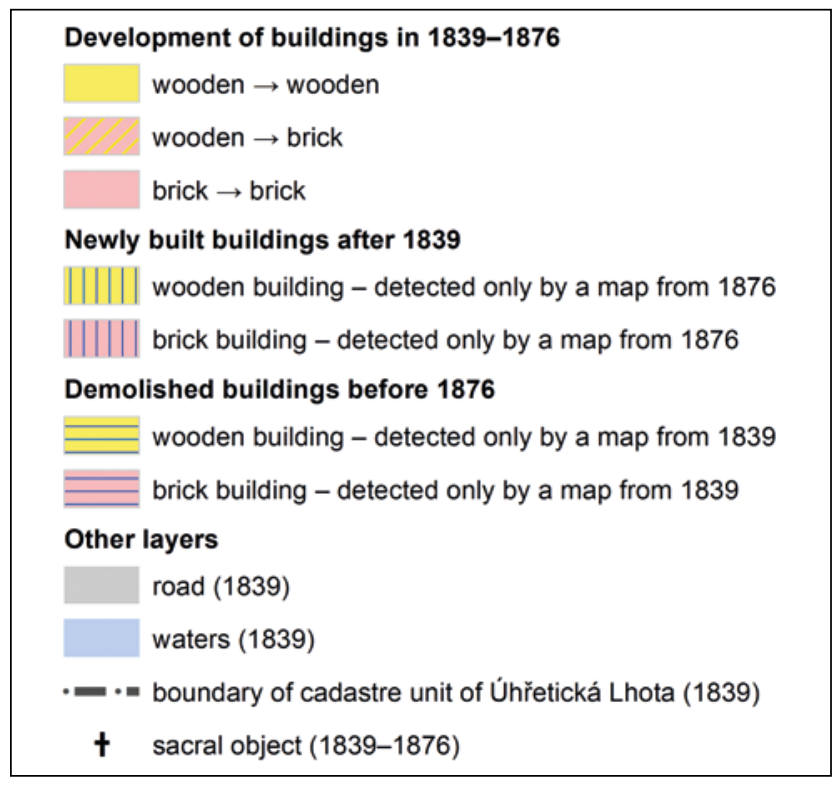

Fig. 12 Example of the detailed map legend.

2. Brick building remained brick walled (brick-brick)

3. Wooden building was transformed into a brick building (wooden-brick)

4. Brick building was transformed into a wooden building (only exceptionally)

If a building (or a part of a building) was on one base map only, four options were distinguished (Erase function):

1. Newly built wooden building

2. Newly built brick building

3. Demolished wooden building

4. Demolished brick building

A graphical representation of each option is shown in the used map legend (Figure 12). The chosen colours evoke the used building material; the hatching direction indicates the construction or destruction of a building.

\subsection{Online presentation of analytical maps}

The created analytical maps of the built-up area development are presented on the website in the vector data format (summary maps) and raster data format (detailed maps). Responsive webpages (ČVUT, FSv 2020) are created for the presentation of all maps and other project results continuously.

For our purposes of the presentation of summary maps, a comprehensive and freely available JavaScript library OpenLayers (OpenLayers 2020) has proven to be a suitable tool that can display both data types vector and raster. This solution allows the users to define map properties such as layer and legend display settings, centre and zoom coordinate settings for the initial map display, spatial limits on map movement, define layer symbology and much more. The vector map layers are presented in the KML format, which was created by exporting from ArcMap software.

In the online presentation, the set of standard layers (Figure 11) is extended by a layer of geographical names, a layer of the current Orthophoto of the Czech Republic and a layer of the digital elevation model (Figure 13). These additional layers are loaded online from the ĆUZZK source servers in the form of a Web Map Service. Thus, historical data about built-up areas can easily be projected to the current state of the landscape and terrain.

For our purposes of the presentation of detailed maps, a simple and freely available JavaScript library OpenSeadragon (OpenSeadragon 2020) has proven to be a suitable tool which works with pyramid raster tiles. The authors chose the Deep Zoom Image (DZI) format for the layout of tiles which is very similar to the solution used by Google Maps. Individual layers of the pyramid are stored separately in numbered folders. The tile file names consist of the column and layer numbers of the grid. For creating pyramid patterns in this layout, there are many applications from

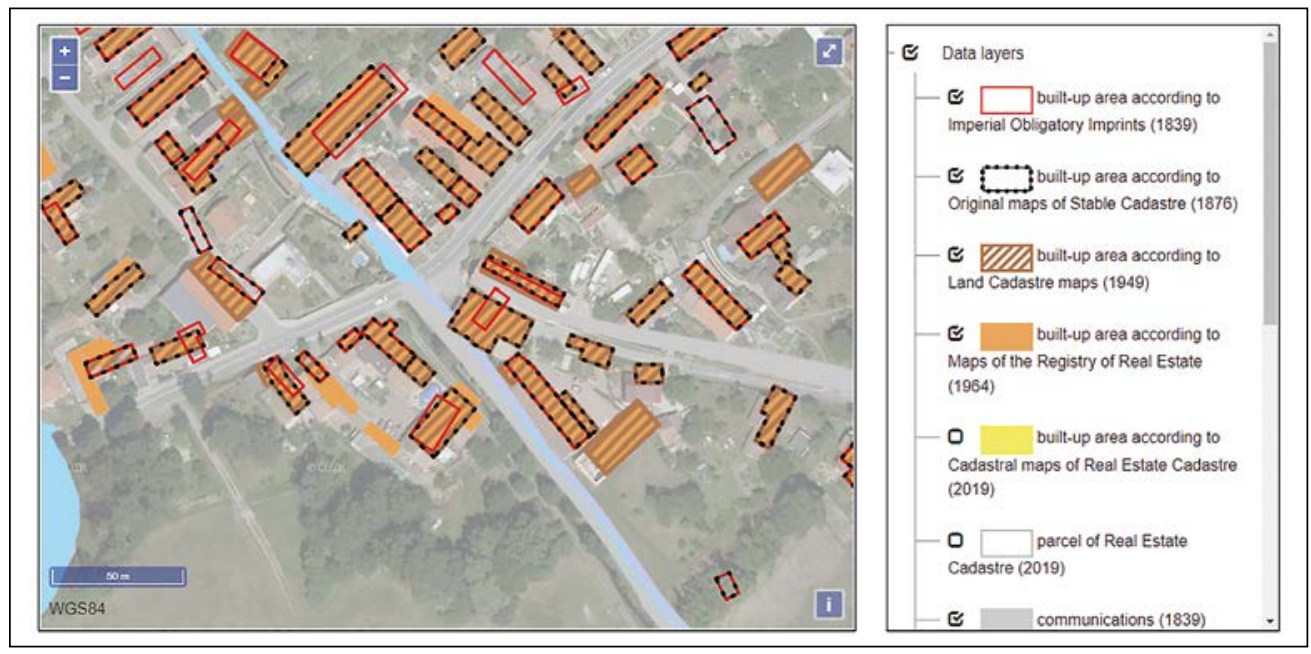

Fig. 13 Web-presentation of the summary map of the built-up area development of the village of Úhřetická Lhota (Pardubice District), detail, data: ÚAZK, ČÚZK.

Online: http://venkov.fsv.cvut.cz/projekt/mapy_vektor/uhreticka_Ihota/uhreticka_lhota_en.html. 


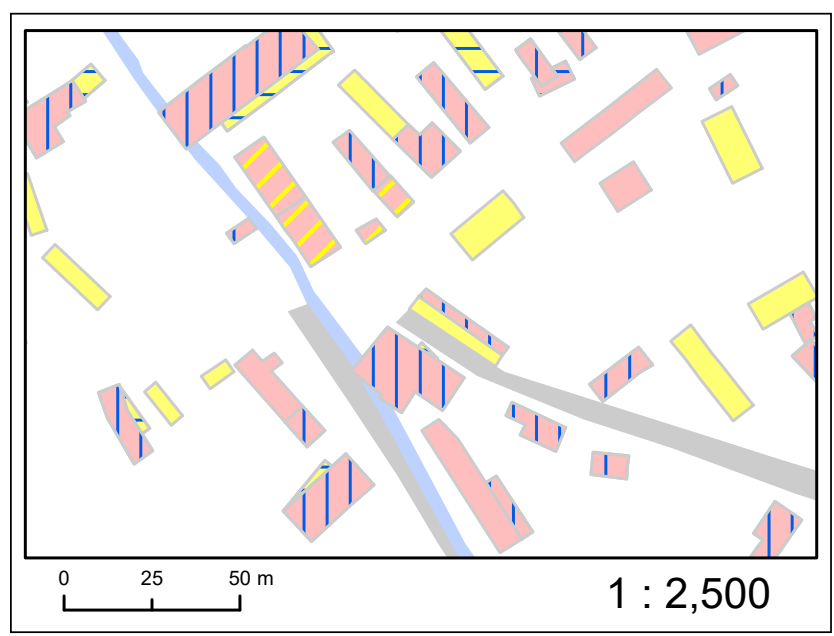

Fig. 14 Web-presentation of the detailed map of the built-up area development of the village of Úhřetická Lhota (Pardubice District), detail, data: ÚAZK, ČÚZK.

Online: http://venkov.fsv.cvut.cz/projekt/mapy_rastr/uhreticka _lhota/uhreticka_lhota_en.html.

various development environments. In this case, the authors used freely available desktop software Deep Zoom Composer from Microsoft (DEEP ZOOM 2020), which allows generating the resulting tiles in JPG and PNG formats. For our purposes, we used the lossless PNG format.

In this way, the whole map sheet is presented online including the map frame with the S-JTSK coordinate grid, legend, map imprint, graphical and numerical scale (Figure 14).

ArcGIS Online (ESRI ArcGIS Online 2020) offers interesting web presentation options as well. Within the student work (Münzberger 2019), outputs using a template that allows effectively comparing different pairs of maps of the same area were presented (Swipe and Spyglass tools).

Web AppBuilder (ESRI Web AppBuilder 2020) offers more advanced options to create a 3D scene for presenting maps of built-up areas on a digital elevation model covered with a current orthophoto (Frommeltová 2019). The application also includes control elements (widgets) allowing working with layers and navigation view (tilt and rotation). As an example of advanced methods of the online presentation of created analytical maps, we can mention a 3D map of a built-up area (Figure 15). The map contains parametrically generated schematized building models. However, this type of output is not used for our needs because it contains a fictional appearance of buildings that could be misleading for subsequent interpretations.

\section{Conclusion}

The article describes practical experience in the creation of analytical maps and possibilities of their

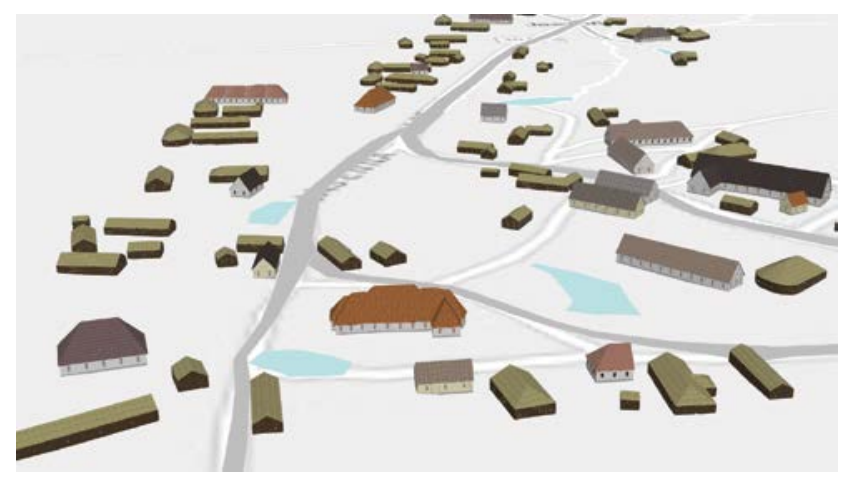

Fig. 15 Web-presentation of 3D models of buildings in Úhřetická Lhota (Pardubice District), detail, data: ÚAZK, ČÚZK.

online presentation. Considerable attention is also paid to available archival datasets. Created maps show the gradual development of built-up areas of selected villages over the last two centuries. They serve as an important basis for the Artistic and Historical Research of rural architecture.

The technological process of creating analytical maps proposed, implemented and described in the article has proved its worth. Careful execution of all phases of the process provides valuable final maps that contain new information on the development of built-up areas in selected localities.

The described procedure could serve as inspiration for research teams resolving similar problems aiming to obtain information from archival data. In this context, the advantage of this article is that it also contains an overview of the main large-scale base datasets, their characteristics and availability.

Analytical maps were created as part of a joint project of the Institute of Art History of the Czech Academy of Sciences and the Department of Geomatics of the Faculty of Civil Engineering of CTU in Prague. Individual stages of the presented workflow were continuously consulted by interested experts from both workplaces.

Analytical maps of the built-up area development have been prepared for 13 carefully chosen villages altogether, equally spread throughout Czechia. The created maps are published on the website and are also available in PDF files.

The outcomes of our research activities are continuously presented to professionals and the general public - through thematic exhibitions (Hůrková, Mezihoráková 2018; 2019), book publications (Hůrková, Mezihoráková 2016; Vlček 2017), academic articles (Hodač, Zemánková 2018; Poloprutský, Soukup, Gruber 2017; Poloprutský 2018; 2019) and workshops for students (Hůrková, Mezihoráková 2017).

The final output of the project will be a publicly accessible database containing complete textual and pictorial documentation drawing on the Artistic and Historical Research of selected villages. Analytical maps will be an integral part of the final database. 


\section{Acknowledgements}

This work was supported by the Ministry of Culture of the Czech Republic from the Programme for the Support of Applied Research and Development of National and Cultural Identity for the Years 2016 to 2022 (NAKI II), grant project "The Transformation of Rural Architecture with Emphasis on the Development of the 19th and 20th Centuries", No. DG16P02H023 (ČVUT, FSv 2020).

\section{References}

Adami, A. (2015): 4D City Transformations by Time Series of Aerial Images. ISPRS - International Archives of the Photogrammetry, Remote Sensing and Spatial Information Sciences, XL-5/W4, 339-344, https://doi .org/10.5194/isprsarchives-XL-5-W4-339-2015.

Beránek, J., Macek, P. eds. (2015): Building Archaeology Survey: A Methodology. National Heritage Institute, Prague.

Bláha, J., Jesenský, V., Macek, P., Razím, V., Sommer, J., Veselý, J. (2005): Operativní průzkum a dokumentace historických staveb. Národní památkový ústav, územní odborné pracoviště středních Čech v Praze ve spolupráci $\mathrm{s}$ ústředním pracovištěm, Praha.

Brůna, V., Cajthaml, J., Elznicová, J., Havlíček, J., Müller, A., Pacina, J., Zimová, R. (2015): Pamět' krajiny Ústeckého kraje ukrytá v mapových archivech: metody rekonstrukce a zpracování dat v oblastech zaniklých obcí. Univerzita J. E. Purkyně v Ústí nad Labem, Fakulta životního prostředí.

Bumba, J. (2009): České katastry od 11. do 21. století. Grada, Praha.

Cadastral Decree (2013): 357/2013 Statute Book, Regulation of State Administration of Land Surveying and Cadastre, https://www.cuzk.cz/Predpisy/Pravni -predpisy-v-oboru-zememerictvi-a-katastru/357-2013 .aspx (29. 2. 2020).

Cajthaml, J. (2012): Analýza starých map v digitálním prostředí na př́kladu Müllerových map Čech a Moravy. ČVUT, Praha.

Cajthaml, J., Kratochvílová, D., Janata, T. (2019): 3D Model of Historical Vltava River Valley: Combination of Sources. Proceedings of the ICA 2(1-5), https://doi.org/10.5194 /ica-proc-2-14-2019.

Cogliati, M., Tonelli, E., Battaglia, D., Scaioni, M. (2017): Extraction of DEMs and Orthoimages from Archive Aerial Imagery to Support Project Planning in Civil Engineering. ISPRS Annals of Photogrammetry, Remote Sensing and Spatial Information Sciences, IV-5/W1, 9-16, https:// doi.org/10.5194/isprs-annals-IV-5-W1-9-2017.

Čurovič, Ž., Popovič, S. (2014): Typological Classification of Settlements in the Rural Hinterland of the Bay of Boka Kotorska. Agriculture \& Forestry / Poljoprivreda i Sumarstvo 4(60), 275-289, http://www.agricultforest .ac.me/paper.php?id=2363 (29.2. 2020).

ČVUT, FSv (2020): Proměna venkovské architektury s důrazem na vývoj v 19. a 20. století. Web pages of the project, http://venkov.fsv.cvut.cz/projekt (29. 2. 2020).

Deep Zoom (2020): Deep Zoom, https://www.microsoft .com/silverlight/deep-zoom/ (29. 2. 2020).
Dittrich, T. (1990): Stavebně historické průzkumy pražských vesnic (Zličín, Lysolaje, Ďáblice, Klukovice). Staletá Praha, 56-81.

Ebel, M., Škabrada, J. (2016): Chalupy v Čechách na historických stavebních plánech II. Argo Praha.

ESRI ArcMap (2020): ArcGIS Desktop, http://desktop .arcgis.com/en/arcmap/ (25. 2. 2020).

ESRI ArcGIS Online (2020): Cloud-Based GIS Mapping Software, https://www.esri.com/en-us/arcgis /products/arcgis-online/overview (29.2. 2020).

ESRI Web AppBuilder (2020): Web AppBuilder for ArcGIS (Developer Edition), https://developers.arcgis.com /web-appbuilder/ (20. 2. 2020).

Frommeltová, E. (2019): Using maps for analysis of urban development of a municipality. Bachelor thesis, ČVUT, Praha, https://dspace.cvut.cz/handle/10467/80047 (29. 2. 2020).

Geoportál ČÚZK (2020): Czech Office for Surveying, Mapping and Cadastre. Access to map products and services, http://geoportal.cuzk.cz/ (29. 2. 2020).

Hauserová, M., Poláková, J. (2015): Pomůcka pro používání základních historických map. Ústav památkové péče, FA ČVUT, Praha, http://pamatky-facvut.cz/download /dokumenty/pomucka.pdf.

Hodač, J., Zemánková, A. (2018): Historical Orthophotos Created on Base of Single Photos - Specifics of Processing. Civil Engineering Journal 3(27), 425-438, https://doi.org/10.14311/CEJ.2018.03.0034.

Hůrková, L., Mezihoráková, K. (2016): House with a Column Arcade in Ropice. Památky Těšínského knížectví. Artefactum, Prague, 179-191.

Hůrková, L., Mezihoráková, K. (2017): Průzkum a identifikace památkových hodnot venkovské architektury 19. a 20. století v bývalé vsi Dušníky (Rudná). Workshop studentů Fakulty architektury ČVUT. Artefactum, Praha.

Hůrková, L., Mezihoráková, K. eds. (2018): Proměny venkovské architektury s důrazem na vývoj v 19. a 20. století I. Artefactum, Praha.

Hůrková, L., Mezihoráková, K. eds. (2019): Proměny venkovské architektury s důrazem na vývoj v 19. a 20. století - vybrané stavby. Artefactum, Praha.

Kuča, K., Kučová, V. (1995): „Ošklivé káčátko“ našeho venkova? Zprávy památkové péče 55(3), 105-110.

Liu, Y. S., Wang, J. Y., Long, H. L. (2010): Analysis of arable land loss and its impact on rural sustainability in Southern Jiangsu Province of China. Journal of Environmental Management 3(91), 646-653, https:// doi.org/10.1016/j.jenvman.2009.09.028.

LMS (2020) Archive of aerial survey photos, https://lms .cuzk.cz/lms/ (29. 2. 2020).

Luhmann, T., Robson, S., Kyle, S., Boehm, J. (2014): Closerange photogrammetry and 3D imaging. De Gruyter, Berlin, https://doi.org/10.1515/9783110302783.

Mencl, V. (1980): Lidová architektura v Československu. Academia, Praha.

Münzberger, J. (2019): Creating and presenting maps of urban development of the Velečín village. Bachelor thesis, ČVUT, Praha, https://dspace.cvut.cz/handle /10467/80049 (29. 2. 2020).

OpenLayers (2020): OpenLayers, https://openlayers.org/ (7. 2. 2020).

OpenSeadragon (2020): OpenSeadragon, https:// openseadragon.github.io/ (20.1.2020). 
Pavelka, K. (2017): Modern documentation methods in cultural heritage and its benefits. Cultural heritage perspectives, challenges and future directions. NOVA publishing, New York, USA, 113-155, Social issues, justice and status.

Pešta, J. (2014): Area research into vernacular architecture and rural settlements. National Heritage Institute, Prague.

Poloprutský, Z. (2018): Metric Survey Documentation as a Basis for Understanding the Development of Rural Architecture. Stavební obzor - The Civil Engineering Journal 27(1), 48-59, https://doi.org/10.14311/CEJ 2018.01.0005.

Poloprutský, Z. (2019): Building Information Model as a Possibility for Digital Reconstruction of the Buildings of Rural Architecture. ISPRS - International Archives of the Photogrammetry, Remote Sensing and Spatial Information Sciences, XLII-5/W2, 53-57, https://doi .org/10.5194/isprs-archives-XLII-5-W2-53-2019.

Poloprutský, Z., Soukup, P., Gruber, J. (2017): Development of rural settlements in the 19th and 20th centuries: creation of analytical map outputs. Dějiny staveb 2017. Klub Augusta Sedláčka, Pilsen, Czech Republic, 235-243.

Škabrada, J. (1999): Lidové stavby: architektura českého venkova. Argo, Praha.

Terminological Dictionary (2020): Terminological Dictionary of Geodesy, Cartography and Cadastre http:// www.vugtk.cz/slovnik/ (29. 2. 2020).

ÚAZK (2020): Central archive of surveying and cadastre, https://archivnimapy.cuzk.cz/ (29.2.2020).

ÚDU (2020): Ústav dějin umění Akademie věd ČR, Institute of Art History: The Czech Academy of Science, https:// www.udu.cas.cz/en/ (20.1.2020).

Veselý, J. (2014): Metric survey documentation of historic buildings for use in heritage management. National Heritage Institute, Prague.

Vlček, P. (2017): Vesnička tesařů Ostrovec (Johannesdörfl). Památky západních Čech VI/VII-2016/2017. Národní památkový ústav, územní odborné pracoviště v Plzni, Plzeň, 39-46, https://www.npu.cz/cs/npu-a-pamatkova -pece/npu-jako-instituce/publikace/32322-pamatky -zapadnich-cech-6-7-2016-2017 (29. 2. 2020). 